Article

\title{
Joint Ventures and Sustainable Development. A Bibliometric Analysis
}

\author{
Javier Muñoz de Prat ${ }^{1,2,+}\left(\mathbb{D}\right.$, María Escriva-Beltran ${ }^{2,+}\left[\right.$, , Roberto Gómez-Calvet ${ }^{1, *,+(\mathbb{C})}$ \\ 1 Business Department, Faculty of Social Sciences, Universidad Europea de Valencia, Paseo de la Alameda, 7, \\ 46010 Valencia, Spain; javier.munoz@universidadeuropea.es \\ 2 Economics and Business Department, Universidad Católica de Valencia, Calle Corona 34, 46003 Valencia, Spain; \\ maria.escriva@ucv.es \\ * Correspondence: roberto.gomezcalvet@universidadeuropea.es \\ + These authors contributed equally to this work.
}

Received: 29 October 2020; Accepted: 26 November 2020; Published: 6 December 2020

\begin{abstract}
One of the most common business strategies in companies' growth and internationalization is the Joint Venture (JV) strategy. This type of entry mode in the global market has contributed to building a more sustainable international market. This type of collaborative business normally happens between firms located either in the same country or located in different countries with different levels of development. This paper presents a thorough cross-bibliometric analysis of studies examining the relation between joint ventures and sustainability published in academic journals during the period from 1997 to 2020 and available in the Scopus Collection. This mapping of the field on the one hand graphically illustrates the publications' evolution over time, and on the other hand, the use of bibliometric methodology shows a picture that clusters the academic research of the relationships among these two topics according to the following criteria: JV type, sustainability criteria, host country groups and activity sectors. In addition, the public or private JVs' nature shows a relation to the type of sustainability, and mainly development and management sustainability. The paper reveals the knowledge gap regarding the connection of these two fields, JV and sustainability, and provides a robust roadmap for further investigation in this field.
\end{abstract}

Keywords: joint ventures; sustainability; bibliometric analysis; triple bottom line; literature review; FDI; internationalization

\section{Introduction}

Over the last century, globalization and internationalization have been key to world economic changes. These changes cause a new composition of demand, directly affecting production [1,2]. Hence corporations have had to adapt their strategy, and in addition Joint Ventures (JVs) have been deemed a form of cooperative linkages or alliance capitalism in order to remain competitive in global terms $[3,4]$. The JV has its origins in the United States' early 20th-century legal doctrine [5] and jurisprudence [6] as the result of agreements for the extraction and exploitation of oil wells and mines in other countries, especially in South America, as well as joining projects or ventures in the USA $[7,8]$.

In fact, the term alliance capitalism [9] has been coined to describe the international expansion of companies based on the interdependence of economies, markets and other companies [10-12]. It pertains, on the one hand, to a transfer of know-how produced by the Foreign Direct Investment (FDI), and on the other hand, to an important dependence on the countries where the JV is carried out $[7,13,14]$. 
These changes require comprehending the JV not only as an entry mode, but also as a source of wealth creation subject to the sustainability parameters. Hence several different JV classifications are needed in order to understand its behavior as a market entry mode and sustainable cooperative legal vehicle. We have structured JV in three main areas: (i) According to the nature that triggers its creation (private or public) [15-19] as will be described in Section 3.5; (ii) Their origin and destination (host and home countries) [20] as described in Section 3.4; (iii) According to economic interests or sector [21] in Section 3.7.

The aim of the present bibliometric analysis is to map the relationship of sustainability in the JV context. The research identifies articles that connect these two concepts and shows a first approach on the relation between a collaborative legal and managerial vehicle-JV-and the principles of sustainability [22,23]. The JV easily adapts to the problems of the business environment, facing the needs of companies and its sustainability [24,25]. However, the implementation of JVs, as a collaborative entity in the global market, is not exempt from the economic, social and environmental tensions established by Hahn et al. [26]. According to the French authors Baptista and Durand-Barthez [8], the JV is "the contractual association, with a limited purpose, which involves the pooling of resources and risks through equal access to decision-making". This implies the existence of three main elements: (i) An alliance or cooperation agreement, which provides flexibility and adaptability to the JV's management [27-29]; (ii) The concept of trust and loyalty between parties, in legal terms "good faith" [30]; and finally, (iii) A balance of power within the governing parties of the JV [31]. This balance of power between the parties is, in most cases, difficult to put into practice and makes necessary an integrative view to accept corporate sustainability [26, 32]. In fact, this equilibrium between the management needs and Sustainable Development Goals is what we aim to map.

This concept of corporate sustainability is based on the framework created in 1987 when the World Commission on Environment and Development (WCED), also known as the "Brundtland Commission", published the report Our Common Future; the concept has remained in the national and international agendas since then $[33,34]$. From governments to firms, sustainability has been used as a concept to describe desirable development paths for societies [26].

In fact, a growing demand by society exists nowadays towards sustainable practices, that has reached its maximum visibility with the 17 Sustainable Development Goals (SDG) [35]. Corporations, as main actors of the global economy, cannot afford being outsiders to this wave and JV becomes a perfect driver to lead this change to sustainable development. This paper analyzes the relationship between JV and sustainability practices in the literature from 1997 to 2020 in order to map the global scientific production through a bibliometric analysis. Hence, this paper updates and identifies the major types and categories of JV within the context of sustainability. Consequently, this research aims to present a more complete evaluation of these two main topics as a practical guide for academics and JV managers.

The article is structured as follows: Section 2 presents the research methodology based on a comprehensive study of existing literature databases. Section 3 identifies six subsections that outline the main authors, keywords and collaboration networks, the nature of the JV, the host country where the JV is created, the type of sustainability mentioned and finally the JV's activity sector. Section 4 concludes by presenting a comprehensive overview of the relation between sustainability and JV as well as showing future research lines.

\section{Methodology}

Assuming the relevance of the JV as an entry mode in national and international markets and the need to develop a corporation that is sustainable in the long run, it is fundamental to understand the literature's evolution on these issues. Hence, we believe that to perform a bibliometric analysis is needed in order to understand how JV and sustainability interact. 
Traditional procedures to review literature have been based on the systematic review of existing documents. This type of analysis is becoming increasingly unfeasible due to the large amount of published documents. Moreover, the large number of academic publications has led to voluminous and fragmented research streams [36]. For literature reviews, academics use different qualitative and quantitative methods to classify and organize the existing research; among these there are several softwares, such as CitNetExplorer, VOS viewer, BibExcel or SciMAT [37]. For this study we used the package Bibliometrix developed by Aria and Curulo in 2017 [38], which is programmed in R [39].

This research study used the SCOPUS collection database, accessed on October 2020 (alternatively, the same initial search was carried out using Web of Science, yielding a similar list of documents). In the first step, the search was carried out using a split search of two terms: words related to JVs and words related to Sustainability. As shown in Figure 1, the first term yielded more than 20,000 documents while the second one gave a larger set of documents. Based on these two searches, we combined both results looking for those documents that simultaneously mention both terms. The exact search strategy was:

("joint ventures" OR "Joint Ventures" OR “joint-ventures" OR "Joint-Ventures") AND ("Sustainab" OR "sustainab") in the TITLE, ABSTRACT and KEYWORDS

Focusing on those documents that simultaneously contain both terms, the set of documents was greatly reduced to 424 studies. Table 1 shows the breakdown according to the type of document. Among these, about $50 \%$ were journal articles and $20 \%$ were conference papers, which can be considered as documents more closely linked to research activity. It is also worthwhile to mention that 47 documents (about $10 \%$ ) were review papers.

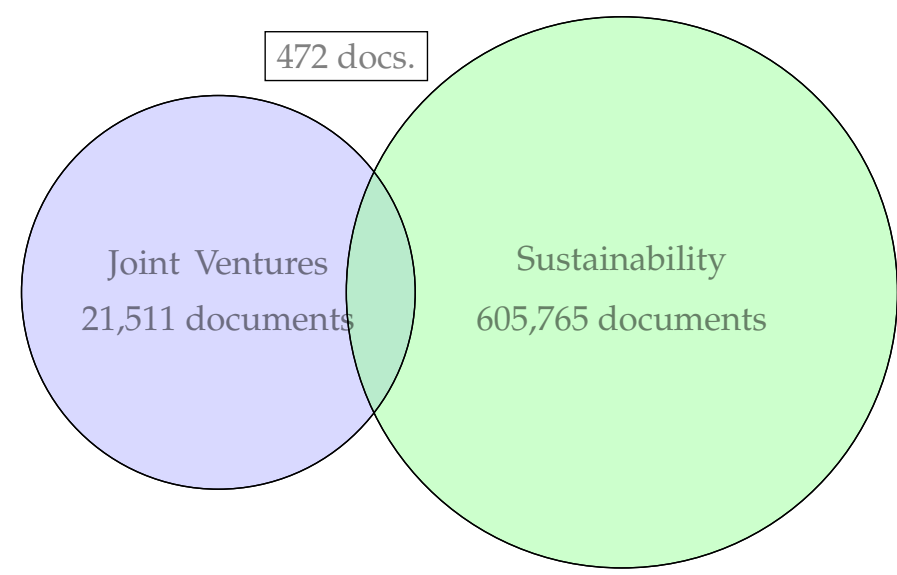

Figure 1. Number of documents found with relevant words in Title, Abstract and Keywords. Search performed in the Scopus database. Accessed 01 October 2020. Source: Authors based on data from the Scopus database. 
Table 1. Search breakdown of documents.

\begin{tabular}{lrr}
\hline Type of Article & Number of Publications & \% Total \\
\hline Article & 235 & $55.42 \%$ \\
Book & 1 & $0.24 \%$ \\
Book Chapter & 17 & $4.01 \%$ \\
Business Article & 10 & $2.36 \%$ \\
Conference Paper & 89 & $20.99 \%$ \\
Note & 11 & $2.59 \%$ \\
Review & 47 & $11.08 \%$ \\
Short Survey & 14 & $3.30 \%$ \\
\hline Total general & 424 & $100.00 \%$ \\
\hline \multicolumn{2}{c}{ Source: Authors based on data from the Scopus database. }
\end{tabular}

We also visualized the most relevant networks of universities and research centers present in the 424 documents analyzed, as shown in Figure 2. We have identified the top five groups of research, where we can distinguish two groups and three individual universities.The individual universities include The University of International Business and Economics from China, which is the biggest node, followed by the University of Hong Kong and Cleveland State University. In the two groups, it is possible to differentiate between the red centers, which represents three research centers from Australia, and the brown centers that come from Malaysia, India (2), Denmark and Germany. The latter is highly interconnected, but in general, the conclusion is that there is a scarcity of connections between the different networks.

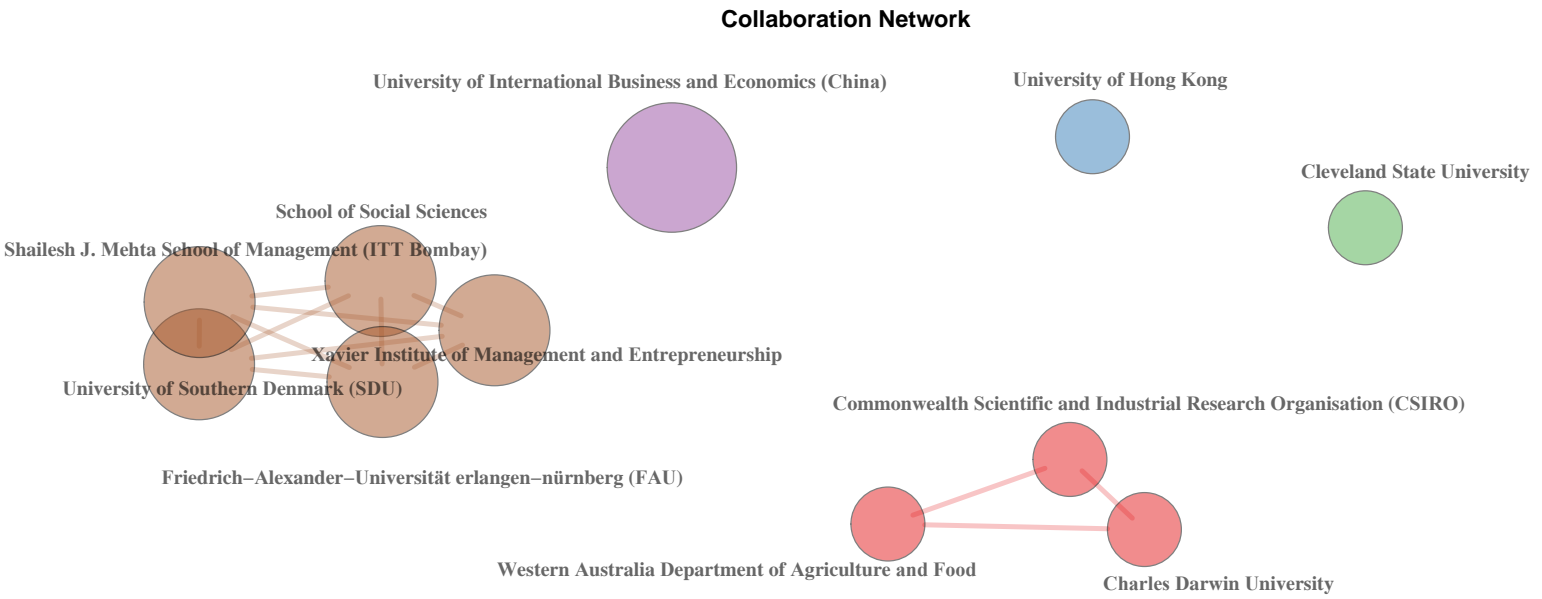

Figure 2. Collaboration networks found among research institutions shown in the analysis of the 424 document analysis. Source: Authors based on data from the Scopus database.

Focusing attention on the source journals we found that three journals concentrate most of the documents; Sustainability, Technovation and Strategic Management Journal. Figure 3 shows these journals jointly with the strength of co-citation connections among them. The scope of these journal is clearly consistent with the aim of JV, where innovation and strategic management inspire most of the JV initiatives. 


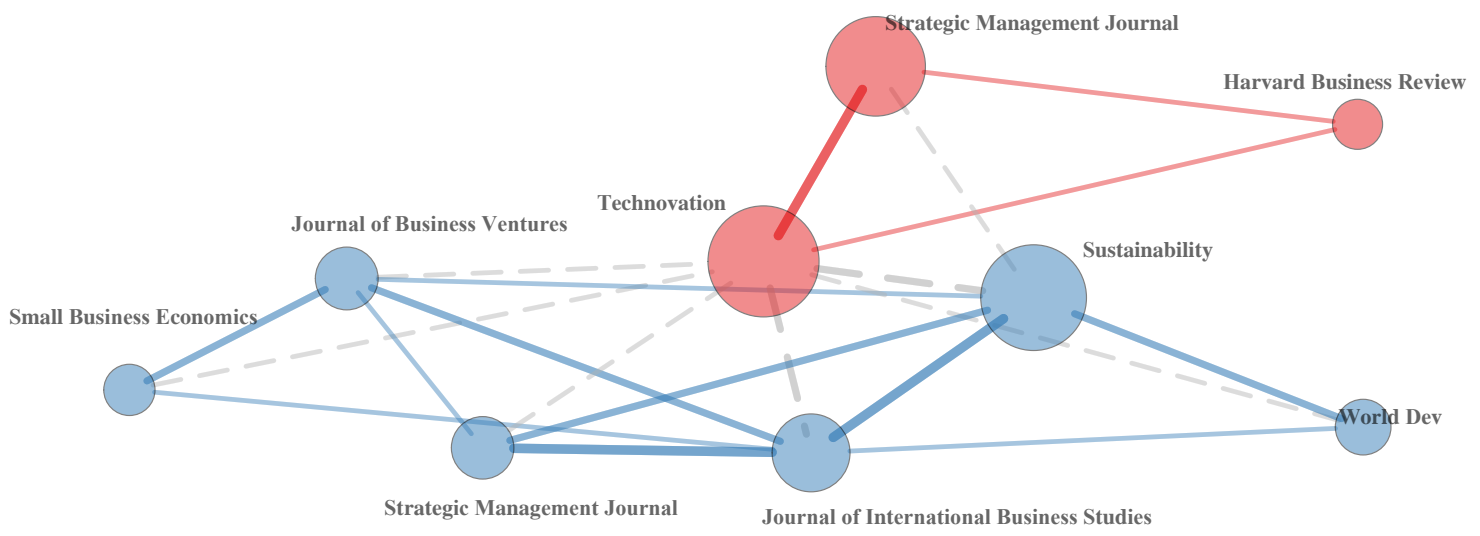

Figure 3. Co-citation among journals shown in the analysis of the 424 document analysis. Source: Authors based on data from the Scopus database.

However, although the research topic is relatively new, Figure 4 shows the keyword co-occurrence of the 12 keywords with a minimum number of seven occurrences. The most recurring keywords are represented in larger nodes (sustainability and JV). The thicker the link between the different nodes, the stronger the relationship between the keywords. The program identified two clusters or groups of words related to each other (nodes of the same color belong to the same cluster). The blue color represents co-occurrences related with China, sustainability and decision making. The red cluster shows a strong relation between JV and sustainable development. The two clusters are highly connected, especially the nodes of China and JV (in blue) and with less strength with project management or innovation (in red). It should be noted that technology transfer showed the smallest amount of co-occurrences. 


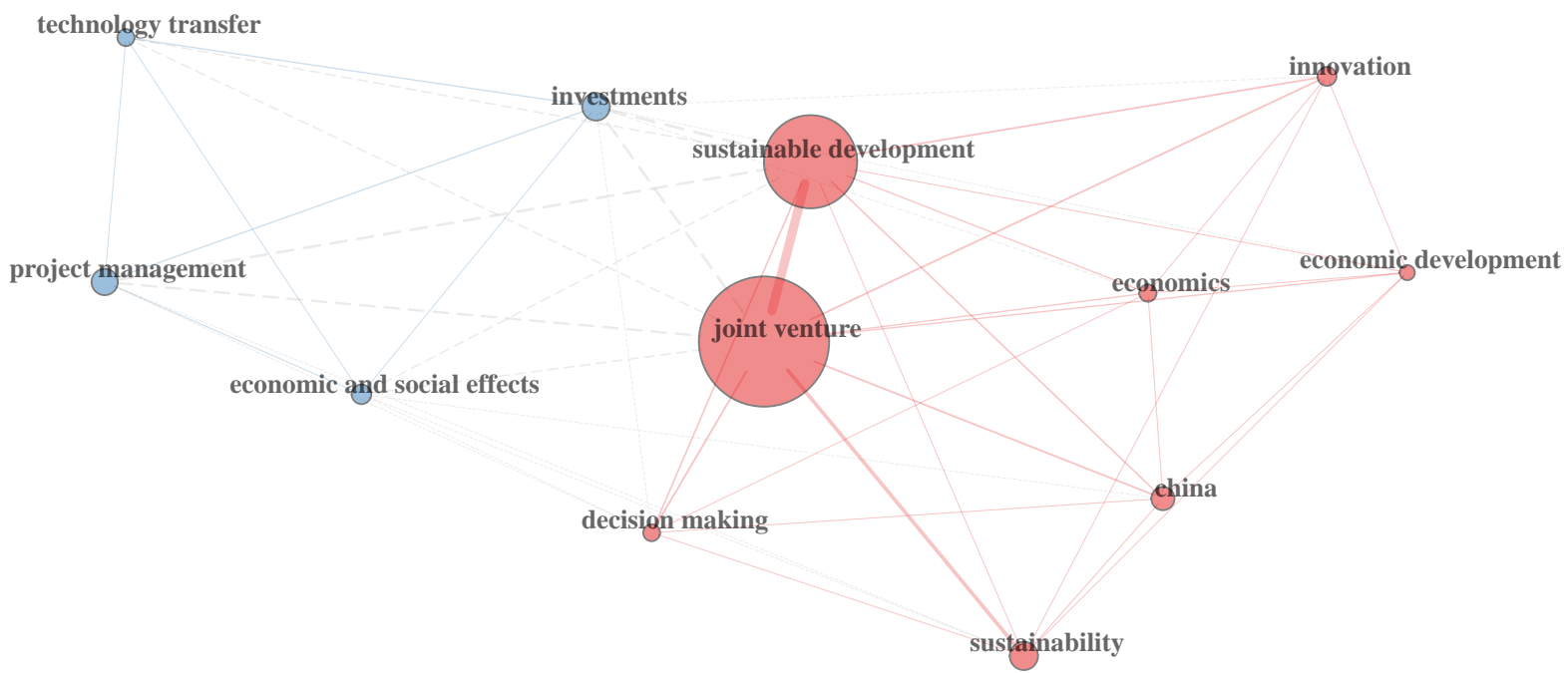

Figure 4. Keyword co-occurrences shown in the analysis of the 424 document analysis. Source: Authors based on data from the Scopus database.

After performing this first layout of keyword co-occurrences and seeing the close relationship between $\mathrm{JV}$, sustainability and sustainable development, another bibliographic search was conducted focusing only keywords in order to narrow down the results to only these items directly related to the connection between the two studied concepts: JV and sustainability.

As a result of this second search, 81 documents were found to be more directly related with the objectives of the paper. The distribution of this type of documents is shown in Figure 5 and Table 2. These 81 documents confirm the reduced extent of the literature concerning JV and Sustainability, and therefore we have used 45 additional academic documents in order to cluster and support our bibliometric review.

Table 2. Narrowed search results.

\begin{tabular}{lrr}
\hline Type of Article & Number of Publications & \% Total \\
\hline Article & 38 & $46.91 \%$ \\
Book & 1 & $1.23 \%$ \\
Book Chapter & 1 & $1.23 \%$ \\
Conference Paper & 20 & $24.69 \%$ \\
Note & 1 & $1.23 \%$ \\
Review & 17 & $20.99 \%$ \\
Short Survey & 3 & $3.70 \%$ \\
\hline Total general & 81 & $100.00 \%$ \\
\hline
\end{tabular}

Source: Authors based on data from the Scopus database. 


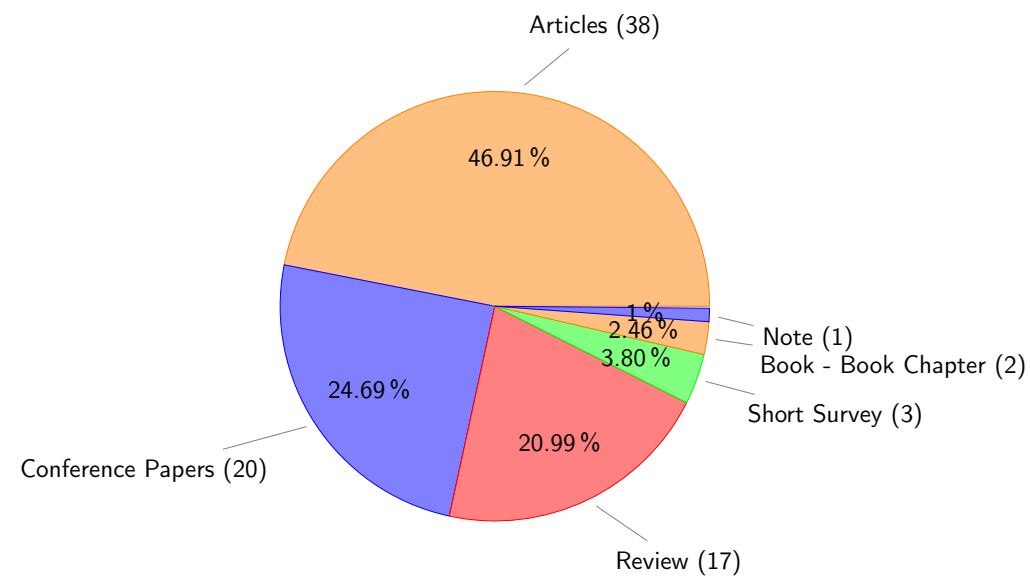

Figure 5. Narrowed search breakdown. Source: Authors based on data from the Scopus database.

\section{Results}

As previously mentioned in Figure 5 and Table 2, this review analyzes 81 publications and identifies the following four clusters:

\subsection{Main Authors and Publication Year}

Table 3 lists the most cited documents. A review from Chertow entitled "Uncovering" industrial symbiosis published in the Journal of Industrial Ecology in 2007 [40] represents 59.02\% of the total of the documents cited. Chertow's article analyzes resource sharing as an environmentally and economically desirable strategy, focusing on an initial sharing economy in the design and building of the eco-industrial parks sector. This article is relevant due to the fact that it explains the consequences that the sharing economy has on corporate collaborative strategies such us the JV. 
Table 3. Ranking of main authors based on number of cites.

\begin{tabular}{|c|c|c|c|c|}
\hline Authors & Reference & Year of Publication & Most Cited & $\%$ Total \\
\hline Chertow M.R. & [40] & 2007 & 569 & $59.02 \%$ \\
\hline Matta J.R., Alavalapati J.R.R. & [41] & 2006 & 38 & $3.94 \%$ \\
\hline $\begin{array}{l}\text { Duff G., Garnett D., Jacklyn P., Landsberg J., } \\
\text { Ludwig J., Morrison J., Novelly P., Walker D., } \\
\text { Whitehead P. }\end{array}$ & [42] & 2002 & 31 & $3.22 \%$ \\
\hline Kumaraswamy M.M., Shrestha G.B. & [43] & 2009 & 31 & $3.22 \%$ \\
\hline Chen J.-Y., Dimitrov S., Pun H. & [44] & 2002 & 29 & $3.01 \%$ \\
\hline Devapriya K.A.K., Ganesan S. & [45] & 2019 & 29 & $3.01 \%$ \\
\hline $\begin{array}{lllll}\text { Kepa Brian } & \text { Morgan } & \text { T.K., } & \text { Sardelic } & \text { D.N., } \\
\text { Waretini A.F. } & & & & \end{array}$ & [46] & 2006 & 26 & $2.70 \%$ \\
\hline Sagers M.J. & [47] & 2012 & 26 & $2.70 \%$ \\
\hline Hosseininia G., Ramezani A. & [48] & 2016 & 23 & $2.39 \%$ \\
\hline Ichijo K., Kohlbacher F. & [49] & 2007 & 21 & $2.18 \%$ \\
\hline Rudie R. & & 2000 & 14 & $1.45 \%$ \\
\hline Shah K.U. & [50] & 2015 & 14 & $1.45 \%$ \\
\hline Maqsoom A., Charoenngam C., Awais M. & [51] & 2013 & 12 & $1.24 \%$ \\
\hline Yun J.J., Lee M., Park K., Zhao X. & [52] & 2019 & 12 & $1.24 \%$ \\
\hline $\begin{array}{l}\text { Toppinen A., Lähtinen K., Leskinen L.A., } \\
\text { Österman N. }\end{array}$ & [53] & 2011 & 11 & $1.14 \%$ \\
\hline Others & & & 78 & $8.09 \%$ \\
\hline Total general & & & 964 & $100.00 \%$ \\
\hline
\end{tabular}

Source: Authors based on data from the Scopus database.

The second most cited article [41], which is far behind Cherton [41], portraits the joining efforts for a shared understanding of the collective action among community members for the JV's success and sustainability. Followed in third place, Duff et al. [42] describe the Tropical Savannas Research Centre as a $\mathrm{JV}$ of major organizations involved in research and land management. The first three articles highlight the collaborative side of the JV, whereas the following three are focused on two different areas: On the one hand, the JV as an entry mode in the construction sector in Sri Lanka [45] and Hong Kong [43], and on the other hand, Chen, Dimitrov and Pun [44] wrote about the international supply chain and the role of the government in order to promote research and innovation.

Following with the most cited articles, up to rank 10, the authors researched Chinese engineering in the Three Gorges Project [46], Russia's oil extraction [47], small and medium food companies in Iran [48] and Toyota's global expansion [49].

The publication dates of the most cited authors are also relevant. Despite the fact that the first source used dates to 1997, the most relevant cites are concentrated in the period from 2002 to 2020. In addition, this review of the top ten most cited articles shows the wide variety of the existing JVs. The JV becomes a vehicle to solve the different problems that companies, communities and government face in order to tackle a complex reality.

Attending to the evolution in the number of publications by year, the distribution of the 81 publications used in this study can be seen in Figure 6. The first article examining the relationships between JV and sustainability appeared in 1997 [54]. The volume of articles published did not show a clear growing trend but an average of four documents were published each year, highlighting 2004 with 11 documents and 2012 with nine, showing a slightly upward trend in 2019 that evidences the growing interest and importance of this novel link between JV and sustainability in the scientific community. 


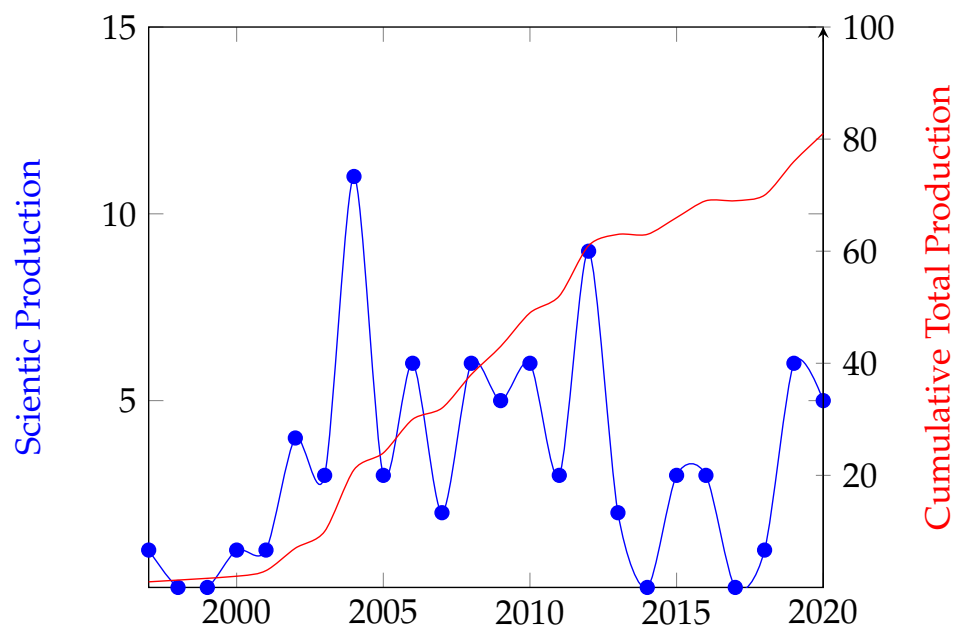

Figure 6. Evolution of research studies with keywords related to sustainability and joint venture. Source: Authors based on data from the Scopus database.

\subsection{Keywords Analysis}

Focusing on the keywords, the most relevant in the literature are: sustainable development, joint venture, sustainability and investments. Figure 7 presents these most relevant keywords in chronological cumulative appearance.

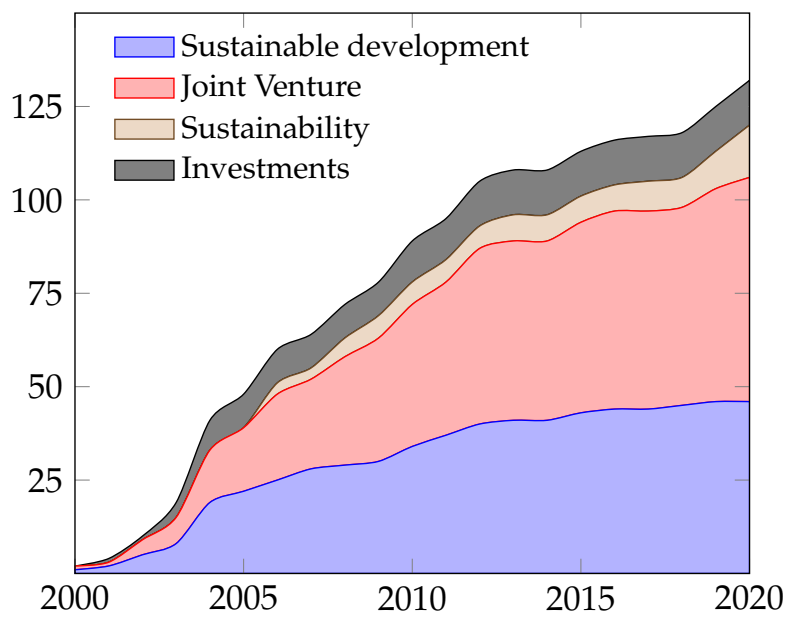

Figure 7. Most relevant keywords' chronological cumulative appearance. Source: Authors based on data from the Scopus database.

\subsection{The Nature of the Joint Venture}

After the keyword analysis was done, a classification was made according to the JVs' nature. In nature, scholars refer to how the parties' personality, which is involved on the formation of the JV, affects its characteristics; see in particular de Lemus [55], Baptista and Durand-Barthez [8] and Pauleau [31].

Depending on the nature or condition of the actors, the JV will have certain characteristics and will be subject to greater (public) or lesser (private) limitations. In practice, when the State is part of a JV together with a private company, it aims to reach an agreement to carry out an action that the State itself could not achieve [56]. In fact, the use of JVs by States (developed or not) has become widespread due to several motivations, not only economic but also political, especially when FDI is involved. In this sense, 
the decisions of the States are mainly influenced by three variables: obtaining financing for certain projects, regulating a specific sector and making possible the transfer of technology and knowledge to its country. Sometimes it has been mandatory to invest in a country through a JV, either with a state agency or with a local company. This would be the case, until recently, in China [57], the Emirates and Algeria, and it continues to be the case in Cuba [58] and North Korea.

As illustrated in Table 4, this classification requires identifying who constitutes the JV, and hence we have classified JV into four main categories attending the nature of the participants:

1. Public: The JV is created between States. The main example was provided by Okafor [59], where an alternative approach to the Nigeria-Cameroon maritime boundary dispute was discussed. Others examples refer to:

i How the US Congress established the Technology Innovation Program (TIP); [60]

ii How two universities collaborate researching in construction techniques [61];

iii How Trinidad and Tobago set legal conditions in order to operate in its oil, gas and chemicals sectors [50];

iv Finally, how a multinational organization, the Asian Development Bank, deals with and advises governments [62].

2. Private and Public: The JV is created between corporations and/or States. In these JVs there is a potential active role of the State. Clear examples are articles related with cities [63,64] and construction $[65,66]$ development and sustainability. For example the development of an eco-city in China [67], house planing in Oxford [68] or the acoustic technology of Oman's airport [69]. The role of technological transference is clear in these JV as in the cases of water [70], oil [47], forest [41] and paper machinery [71] and engineering in the Three Gorges Project [46] among others. There is also a notable component of learning processes [72-75] and corporate structure [44,76,77].

3. Private and Private: The JV is created between companies regardless of their size and national backgrounds. This is the most used system of JV creation, since it adjusts to the standard definition and the common purpose of this strategic growth collaborative vehicle, as seen in Table 4 . In order to clarify this category, we will highlight some examples:

i Startups and growth [78];

ii Foreign venture capital in India [79];

iii Supply chain sustainability [80];

iv Creating value [81] vs. risk culture [82];

v Technological development $[43,83]$;

vi New product development [84];

vii SMB investment modes and sustainability entrepreneurship $[48,51,85]$.

4. Inner company: The JV is created by a corporation within itself. This last classification could be subsumed under the previous one, but following the bibliometric analysis, we have decided to mention it separately. An example of this particular JV is explained in Toyota's internationalization and strategic growth article [49]. Ichijo described how to transfer knowledge from a Japanese corporation to its subsidiaries. Other examples are: Petronim's risk assessment process in Trinidad and Tobago [86], the DuPont Renewable Sourced Materials subsidiary [87], the development and the design by the MacArthur's River Joint Venture of an ore loading and transportation system [54], and how Besicorp Empire Development Co. (BEDCO) created a mill [88]. 
Table 4. Nature of Joint Venture (JV).

\begin{tabular}{lcl}
\hline Nature of JV & Number of Publications & Reference \\
\hline Public & 5 & {$[50,60-62,89]$} \\
\hline Inner Company & 6 & {$[49,54,86-88,90]$} \\
\hline Private \& Public & 30 & {$[40-42,44,46,47,59,63-77,91-98]$} \\
\hline Private \& Private & 40 & {$[43,45,48,51-53,77-85,99-123]$} \\
\hline Total & 81 & \\
\hline
\end{tabular}

Source: Authors based on data from the Scopus database.

As presented in Table 4, there is a strong interest in the literature regarding JVs among private companies (round $50 \%$ of the publications) and between private and public partners (37\% of the publications). Thus, our results show that the vast majority of the literature focuses on the JV as a private legal and managerial vehicle, which indicated it is used more by corporations and even small companies relative to States. It is relevant to underline that the JV's nature is based on the free will and the autonomy of the parties.

Finally, the JV, regardless of its nature, public and/or private, is a business and legal vehicle closely linked to the entry modes in markets and the growth strategy of the company. This can affect different aspects of its general strategy, such as competitive advantage, internationalization, technology transfer and innovation, among others, as noted below.

\subsection{Host Country Type}

To analyze the main trends related to JV and sustainability it is important to focus on the JV host country. Attending to the documents analyzed, we have grouped all the publications into five main items according to the country that hosts them: developed countries, BRICS, developing countries, global JV and others, as presented in Table 5:

Table 5. Host Country type.

\begin{tabular}{lcl}
\hline Host Country Groups & Total & Reference \\
\hline Developed Countries & 31 & $\begin{array}{l}{[40,42,43,49,52-54,60,63-65,68,72,73,81,83,87,88,92,99,102,} \\
105,106,113,114,116-121]\end{array}$ \\
\hline BRICS & 18 & {$[41,46,47,67,70,71,76,77,79,82,89,93,100,104,109,111,122,124]$} \\
\hline Developing Countries & 17 & {$[45,48,50,51,59,61,62,69,75,80,86,91,94,96,97,103,110]$} \\
\hline Global JV & 12 & {$[44,66,74,78,84,85,90,97,101,108,115,123]$} \\
\hline Others & 3 & {$[95,107,112]$} \\
\hline Total & 81 \\
\hline & Source: Authors based on data from the Scopus database.
\end{tabular}

JVs dealing with sustainable issues are equally hosted in both BRICS and developing countries, but Table 5 also shows the relevance of the developed countries. This classification coincides with the JV origins explained in Section 1, and hence the primitive USA JVs were created as an entry mode in a foreign market (mainly South America) as well as a way to consolidate the North American market. In the developed countries the host and home country coincide. The USA (9) $[60,83,87,88,99,105,113,116,117]$ is in the top publication ranking followed by Australia (5), UK (4) [65,68,72,120] and Canada (4) [54,63,92,119], and the remaining publications belong mainly to Europe, Japan, Hong Kong and South Korea. The acronym BRICS refers to what O'Neil first described in Building Better Global Economic BRICS [125] as 
emerging economies (Brazil, Russia, India, China and later on South Africa). This classifications ranks at the third position in Table 5, although the majority of publications belong to China (11) $[46,67,70,71,77$, $82,93,111,122,124,126]$, followed by India (5) [41,76,79,100,104], Russia [47] and South Africa [89]. In the case of China, it increases its numbers if we take into account publications that include Asia $([94,98,103])$ and home countries $([46,62,109,110])$. Nevertheless, the main publication area is related to developing countries. We would like to highlight the absence of South America in the sources studied, whereas there exists a predominance of Asia in the publications that are related with Malaysia ([61,110]), Vietnam and Laos) followed by Africa ([50,51,59,69,86,89] and the Middle East $([48,51,69])$.

By global JV, it is important to remark upon JV patterns that serve any company in a transverse way, regardless of which is the host and which is the home country. These publications present a model were many JVs can be measured and studied.

\subsection{Nature of the Firm vs. Host Country}

Taking into consideration the characteristics presented in the previous sections, cross-sectional data will be shown in a graphic way. For each type of JV identified, a figure will show how many publications were found for each host country group. According to the results, apparently Figures 8 and 9 do not show a clear branch of knowledge for scholars' interests. On the contrary, the biggest interest is shown for private and public (Figure 10) and private and private (Figure 11). As can be seen, the most productive host countries in terms of research interest are BRICS and developed countries.

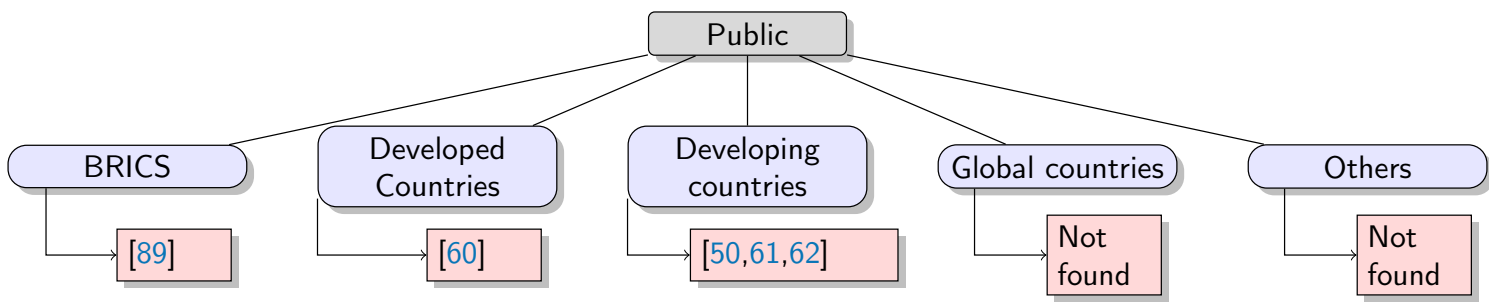

Figure 8. Public nature of JV by host country. Source: Authors based on data from the Scopus database.

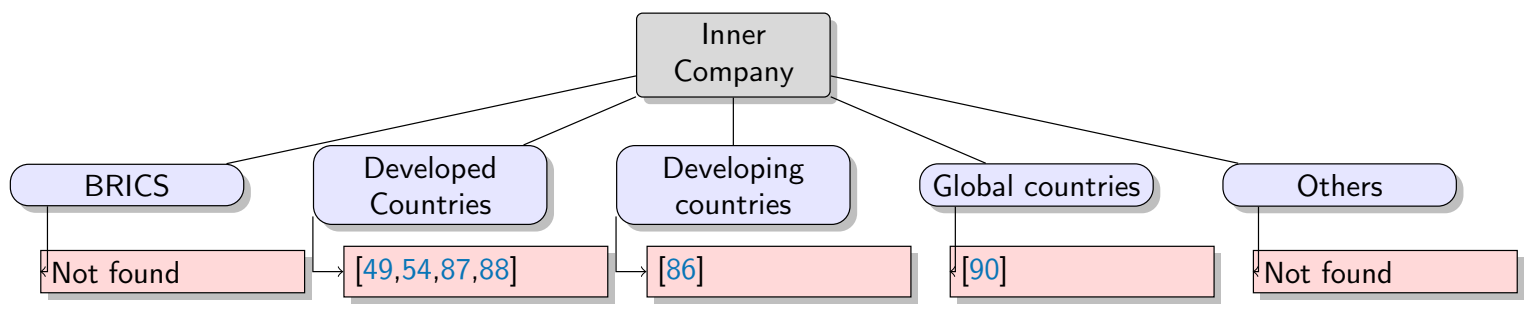

Figure 9. Inner company nature of JV by host country. Source: Authors based on data from the Scopus database. 


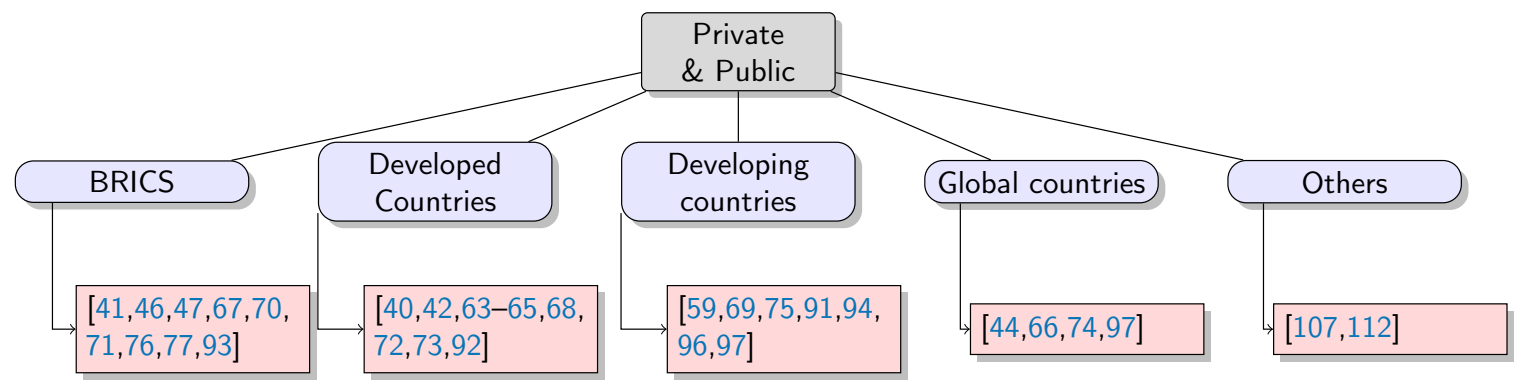

Figure 10. Private and public nature of JV by host country. Source: Authors based on data from the Scopus database.

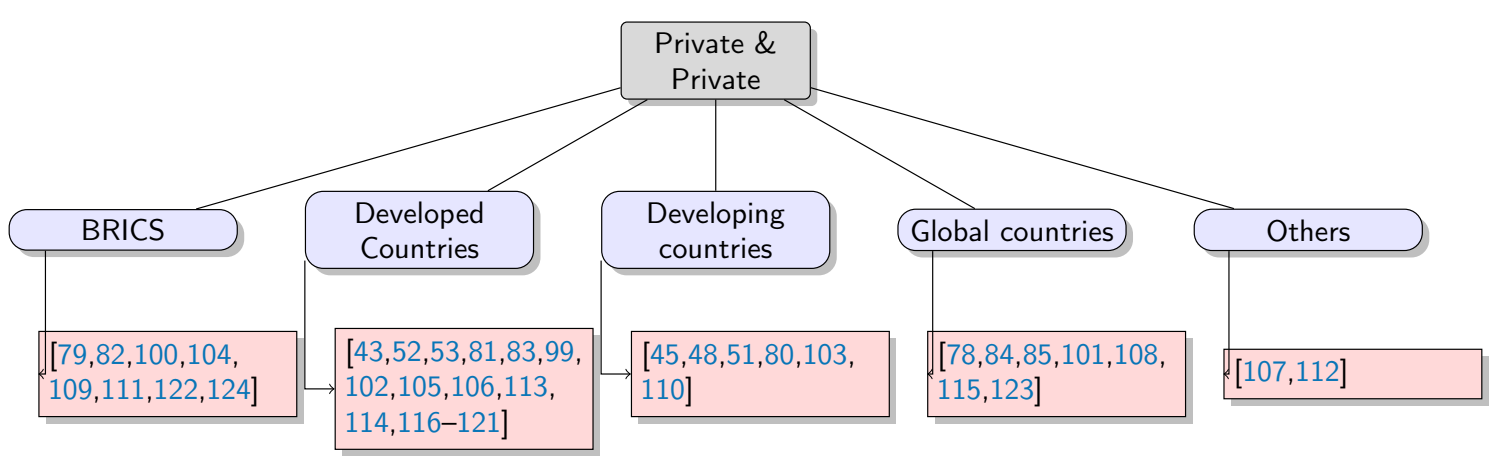

Figure 11. Private and private nature of JV by host country. Source: Authors based on data from the Scopus database.

\subsection{Sustainability}

In relation with sustainability, important research parallelisms with the principles of sustainability stated in the triple bottom line (TBL) defined by Elkington were found [32]. According to his three P's approach (People, Planet and Production), the articles found have been grouped into four categories: environmental, production, development and, finally, management sustainability, as shown in Table 6 . This categorization (some kind of concentration) does not imply an illusory simplicity in the sustainable area, but an academic classification in order to understand the different sustainability fields. To some extend, managerial sustainability refers to daily basic corporation actions, while sustainable development is applicable to long-run strategies. Sustainable development and production sustainability are similar; however we have decided to separate them in order to enhance JV committed to product development. The last classification, environmental sustainability, applies to a green environmental approach to sustainability and JV.

Table 6. Sustainability type.

\begin{tabular}{lcl}
\hline Sustainability Type & Number of Publications & References \\
\hline Enviromental Sustainability & 9 & {$[50,53,54,73,86,95,102,109,121]$} \\
\hline Production Sustainability & 15 & {$[44,47,49,59,65,84,85,87,90,99,104,106,108,117,120]$} \\
\hline Sustainable Development & 23 & {$[40,41,45,60-64,67,71,72,76,77,83,88,91,94,96,98,103,105,107,122]$} \\
\hline Management Sustainability & 34 & {$[42,43,46,48,51,52,66,68-70,74,75,78-82,89,92,93,97,100,101,110-116,118,119,123,124]$} \\
\hline Total general & 81 & \\
\hline & Source: Authors based on data from the Scopus database.
\end{tabular}

The most prolific area of sustainability studies is management sustainability, which includes 34 publications, where topics related to the management of the organization (corporation) are 
developed. It is relevant to quote some of the main topics: Economic environment $[46,100,111]$, tech exchange [43,118], eco social [92,113,114], competitive advantage [66,124], best practices [79,81,82,110], supply chain [80] and human resources [115]. They include diverse topics related to the following sectors: Construction-landscape [42], acoustic issues [69], housing [68] and engineering [46,66,110]. Management, either in big corporations $[74,75,79,93,100]$ or SMB $[43,48,51,52]$. Natural Resources-especially water [70, 89,92], startups [78] and chemical/biotech [87].

The second most studied area is sustainable development, which contains 23 publications. The publications can be split into tech transfer [45,96], growth $[103,105,124]$, innovation $[60,61,71,91]$, business strategies [83] and financing [62,99]. It is remarkable to note the number of publications related with cities' development [61,63,88,88], followed by different types of development: Subcontracting [45], financing [62], innovation [60], ownership [67] and labour [96], among others.

The third area illustrated by the table is production sustainability, with 15 publications. These publications can be split in two: Sustainable product innovation $[65,85,87,99,106,117]$ and sustainable production $[47,90,104,108,120]$. Finally, environmental sustainability is the area with the lowest interest in terms of JV sustainability relationship publications; it contains publications on miscellaneous subjects.

The third and fourth areas include works where the JV responds to environmental aspects, including articles exclusively related to production and environmental sustainability. In fact, sustainable production focuses on the creation or improvement of a product. The topics researched go from the creation of new machinery [108], the improvement of processes in the forest [117], oil [59] and automotive industry [49] to the creation of polymers [43,84]. Concurrently, the references on environmental sustainability develop, on the one hand, oil [86] and civil engineering themes [121], and on the other hand, articles that introduce production sustainability concepts [50,53,54,73,95,102,109].

\subsection{Sustainability and Activity Sector}

Table 7 shows the JVs' activity sectors according to its objectives. As can be seen, the top five most studied activity sectors are: Construction, mining, natural resources and chemical/biotechnology.

For a better understanding of the documents analyzed and a consequent mapping of the literature, we performed a three-step grouping. Thus we have combined the JVs' nature Section 3.3 with the type of sustainability Section 3.6 and the JVs' activity sector (Table 7). As a result, four figures conceptualize and map our previous categories: Figures 12-15.

When JVs are public (Figure 12), scholars focus on sustainable development linked to three sectors: construction [61], energy/electric [62] and telecommunication [60]. On the contrary, if we center on inner company JVs (Figure 9), publications are related to production sustainability, paying attention to the activity sectors of mining [90], chemical/biotechnology [87] or the car industry [49].

As seen in Section 3.2, the most studied JV types are private and public and private and private (Table 4), but differences can be seen in Figures 14 and 15. When the nature of the JV is between private corporations, publications are more oriented toward management sustainability. By contrast, when the JV is created by private and public corporations, studies pay greater attention to sustainable development. These differences are based on the motivation behind the JVs' creation, as seen in Section 1 and 3, where the differences of private and public goals are stated. Public JVs are usually intended to protect or develop a key national sector. Even though we have confirmed a coincidence between some of the sectors studied, the main differences reside in the managerial corporation behavior. 
Table 7. Activity Sector.

\begin{tabular}{lcl}
\hline Activity Sector & Number of Publications & Reference \\
\hline Construction & 13 & {$[43,45,46,51,61,65,66,68,69,81,89,110,121]$} \\
\hline Mining & 10 & {$[47,50,54,59,73,86,90,98,99,102]$} \\
\hline Natural resources & 10 & {$[41,42,63,70,83,92,95,97,113,117]$} \\
\hline Chemical/Biotechnology & 9 & {$[84,87,96,105,107,108,116,119,122]$} \\
\hline Energy/Electric & 6 & {$[62,88,94,106,109,111]$} \\
\hline Management & 6 & {$[74,75,79,80,100,115]$} \\
\hline Telecommunication & 6 & {$[52,60,72,101,103,114]$} \\
\hline General & 3 & {$[44,76,77]$} \\
Industrial & 3 & {$[40,53,71]$} \\
\hline Infrastructures & 3 & {$[64,67,91]$} \\
\hline Textile & 3 & {$[104,120,123]$} \\
\hline Car Industry & 2 & {$[49,93]$} \\
\hline Entrepreneurship & 2 & {$[48,78]$} \\
\hline Airlines & 1 & {$[112]$} \\
\hline Capital Market: Securities & 1 & {$[82]$} \\
\hline Hospitality & 1 & {$[77]$} \\
\hline SME & 1 & {$[85]$} \\
\hline Transportation & 1 & {$[118]$} \\
\hline Total & 81 & \\
\hline & & \\
\hline
\end{tabular}

Source: Authors based on data from the Scopus database.

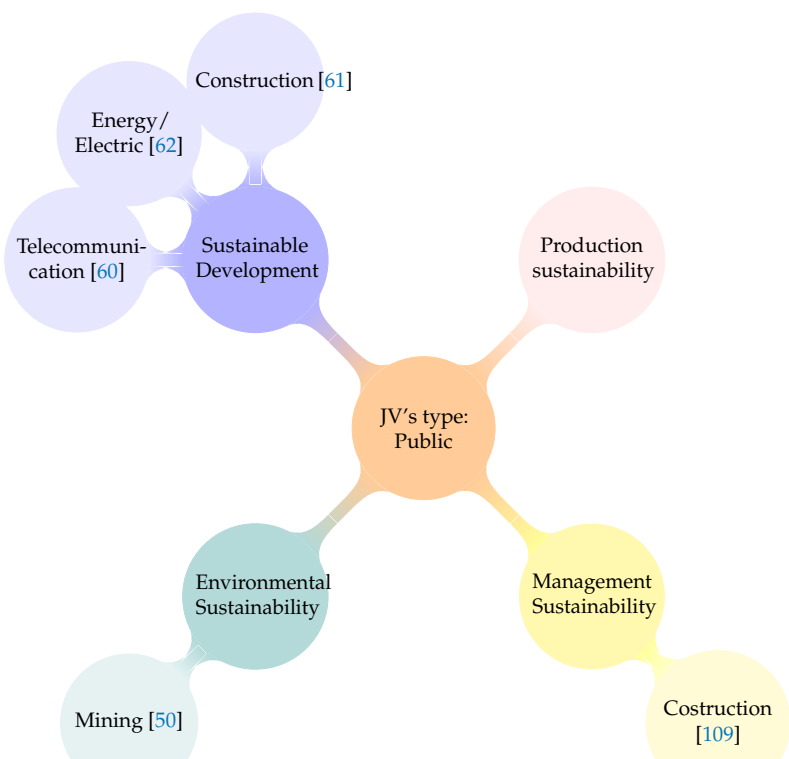

Figure 12. JV types: Public vs. activity sector. Source: Authors based on data from the Scopus database. 


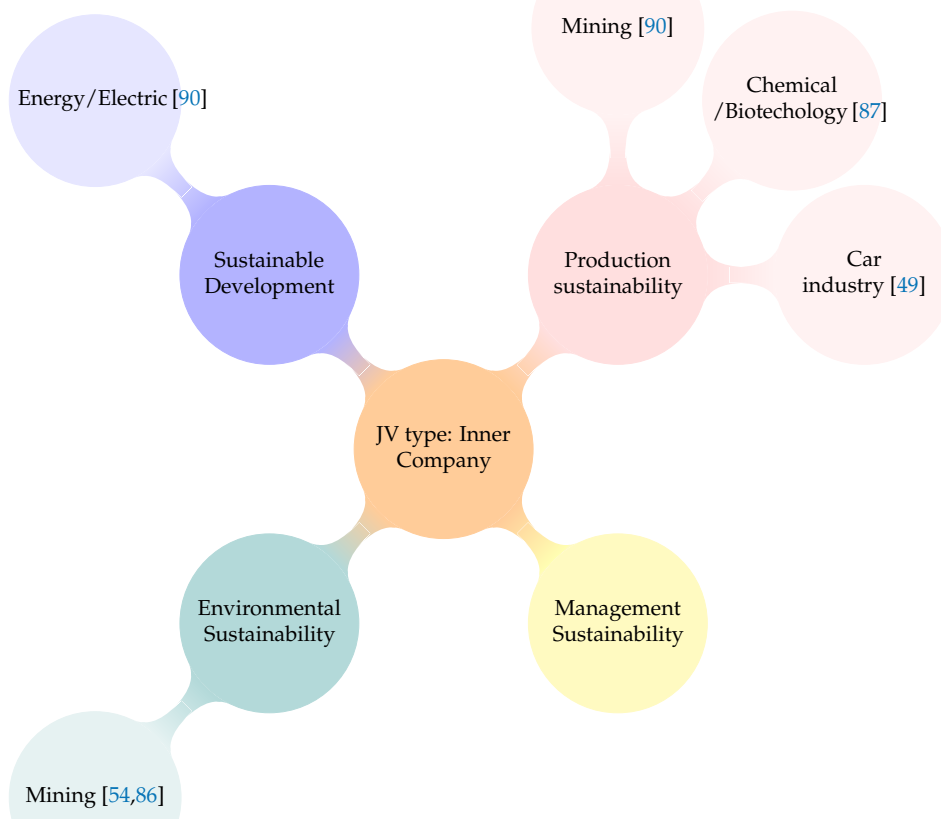

Figure 13. JV types: Inner company vs. activity sector. Source: Authors based on data from the Scopus database.

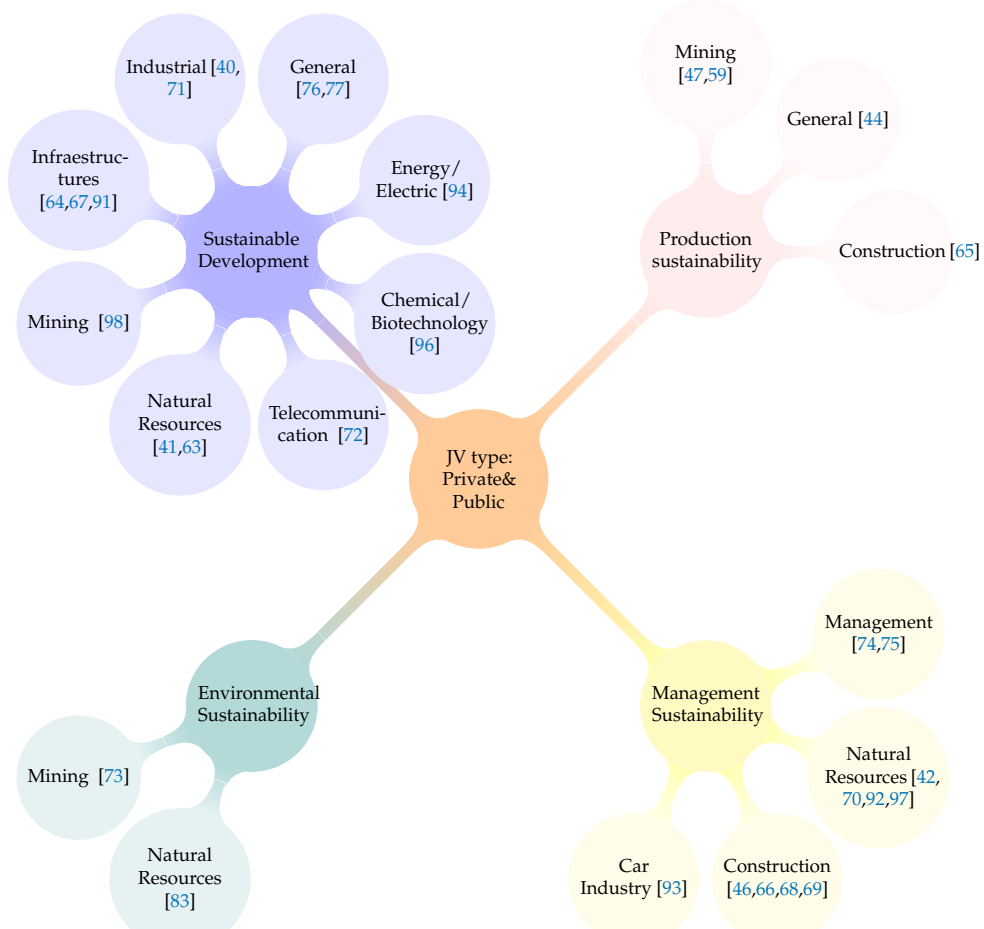

Figure 14. JV types: Private and public vs. activity sector. Source: Authors based on data from the Scopus database. 


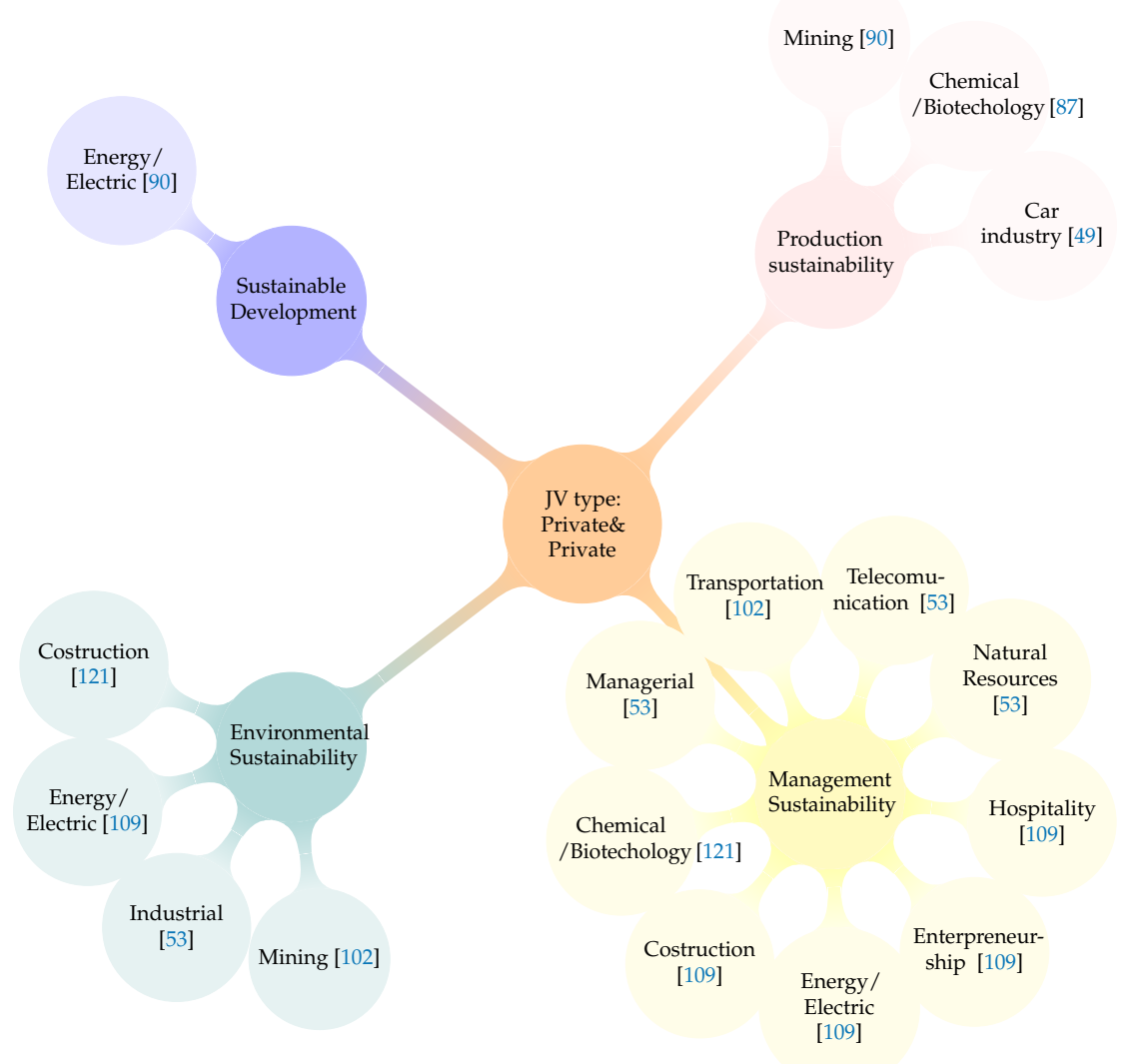

Figure 15. JV types: Private and private vs. activity sector. Source: Authors based on data from the Scopus database.

\section{Conclusions}

Joint venture and sustainability are key concepts in the present globalized business market, although the second concept is by far much more deeply studied. Nevertheless, sustainability has evolved from an emerging trend in the late nineties based on the seminal document of the Brundtland Commission into a priority in 2020 with the Sustainable Development Goals (SGD), from governments to corporations.

The main contribution of this study relies on a bibliometric analysis that pivots around six different results, which shed light on the relation between sustainability and JV. Despite the scarcity of documents found, the descriptive character of the paper contributes first and foremost to discovering emerging directions of research in the combination of the sustainability and the JV. We showed scholars' interest in JVs of private and public and private and private nature, focusing on developed and BRICS countries. It is relevant, as well, to emphasize the polarization of the research interests depending on the nature of the JV. There is an interest with sustainable development in the case of private and public JV, and in opposition, the private and private JV focuses interest on management sustainability.

The apparent scarcity of documents reveals nothing more than an opportunity to deepen this relationship as a new field of study. As far as we know, there are few contributions related with sectors such as tourism, the food industry, agriculture and services-especially in relation with FDI, despite the importance of JV in the international growth of these sectors. In this sense, we believe that the interaction between JV and sustainability from the point of view of the management should be considered in much 
more detail, in a manner aligned with Figure 15. All in all, the JV, despite being one of the most useful collaborative and market entry modes, and being perceived as a practical tool by the majority of studies in the literature, needs further analysis, especially from the perspective of sustainability.

Further research could be aimed at studying the impact of the JV on the country where it is located in light of different legal systems in the home and host companies' countries and in terms of the level of socio-economic development across countries. It should also be noted that the level of implementation of the 17 SDGs could be in different stages depending on the country; hence the JV management must avoid a conflict of interests between countries and companies when developing a sustainable business.

Author Contributions: All authors contributed equally to this work. All authors have read and agreed to the published version of the manuscript.

Funding: This work was supported by the Universidad Católica de Valencia "San Vicente Mártir" under Grant [number 2019-808-001].

Acknowledgments: Maria Escrivà-Beltran acknowledges the financial support of the Research Challenges Programme of MICINN (Spanish Government \& FEDER) (RTI2018-100899-B-I00). Roberto Gómez Calvet acknowledges the financial support of the Research Challenges Programme of MICINN (Spanish Government \& FEDER) (RTI2018-100983-B-I00).

Conflicts of Interest: The authors declare no conflict of interest.

\author{
Abbreviations \\ The following abbreviations are used in this manuscript: \\ BEDCO Besicorp Empire Development Co. \\ BRICS Brazil, Russia, India, China and South Africa \\ DOAJ Directory of open access journals \\ FDI Foreign Direct Investment \\ JV Joint Venture \\ SDG Sustainable Development Goals \\ SMB Small and Medium Business \\ TBL Triple Bottom Line \\ TIP Technology and Innovation Program \\ WCED World Commission on Environment and Development
}

\title{
References
}

1. Tanganelli, D. Joint Ventures internacionales entre PYMES de la Unión Europea; Thomson Reuters-Civitas: Albuquerque, NM, USA, 2004.

2. López Zamarripa, N. El contrato de la Joint Venture en el escenario del comercio global. Amic. Curiae. Segunda Época 2011, 1, 1-20.

3. Park, S.H.; Kim, D. Market valuation of joint ventures: Joint venture characteristics and wealth gains. J. Bus. Ventur. 1997, 12, 83-108. [CrossRef]

4. Kogut, B. Joint ventures: Theoretical and empirical perspectives. Strateg. Manag. J. 1988, 9, 319-332. [CrossRef]

5. Rowley, S. The Modern Law of Partnership: Including a Full Consideration of Joint Adventures, Limited Partnerships, and Joint Stock Companies, Together with a Treatment of the Uniform Partnership Act; Bobbs-Merrill Company: Indianapolis, IN, USA, 1916; Volume 1.

6. Conde Granados, J.L. Análisis del contrato de Joint Venture y sus mecanismos de financiamiento. Vox Juris 2014, 27, 47.

7. Puyo Arluciaga, A. La "Joint Venture" como instrumento de cooperación en el comercio internacional. Gizarte Ekon. Euskal Aldizkaria Rev. Vasca Econ. Soc. 2011, 3, 111-132. 
8. Baptista, L.O.; Durand-Barthez, P. Les Joint Ventures Dans le Commerce International; Primento: Brussels, Belgium, 2013.

9. Dunning, J.H. Reappraising the eclectic paradigm in an age of alliance capitalism. In The Eclectic Paradigm; Palgrave Macmillan: London, UK, 2015; pp. 111-142.

10. Dunning, J.H.; Narula, R. The R\&D activities of foreign firms in the United States. Int. Stud. Manag. Organ. 1995, 25, 39-74.

11. Gulati, R. Alliances and networks. Strateg. Manag. J. 1998, 19, 293-317. [CrossRef]

12. Esteban de la Rosa, F. La Joint Venture en el Comercio Internacional; Comares: Granada, Spain, 1999.

13. Merchant, H.; Schendel, D. How do international joint ventures create shareholder value? Strateg. Manag. J. 2000, 21, 723-737. [CrossRef]

14. Amici, A.; Fiordelisi, F.; Masala, F.; Ricci, O.; Sist, F. Value creation in banking through strategic alliances and joint ventures. J. Bank. Financ. 2013, 37, 1386-1396. [CrossRef]

15. Kogut, B.; Singh, H. The effect of national culture on the choice of entry mode. J. Int. Bus. Stud. 1988, 19, 411-432. [CrossRef]

16. Hennart, J.F. The transaction costs theory of joint ventures: An empirical study of Japanese subsidiaries in the United States. Manag. Sci. 1991, 37, 483-497. [CrossRef]

17. Rugman, A.M.; Verbeke, A. Foreign subsidiaries and multinational strategic management: An extension and correction of Porter's single diamond framework. Manag. Int. Rev. 1993, 33, 71-84.

18. Inkpen, A.C.; Currall, S.C. The coevolution of trust, control, and learning in joint ventures. Organ. Sci. 2004, 15, 586-599. [CrossRef]

19. Rialp Criado, A.; Martínez Carazo, P.C.; Rialp Criado, J. El desarrollo exportador de las pymes industriales españolas participantes en un consorcio de exportación: Un estudio de caso. Cuad. Gestión 2005, 5, 95-116.

20. Langefeld-Wirth, K.; Garcia, A. Les Joint Ventures Internationales: Pratiques et Techniques Contractuelles des Coentreprises Internationales; GLN Joly éd.: Paris, France, 1992.

21. García López, G.A. Join Venture: Generalidades y Clasificación. Available online: https://archivos.juridicas. unam.mx/www/bjv/libros/8/3984/27.pdf (accessed on 29 October 2020).

22. Hart, C. Doing a Literature Search: A Comprehensive Guide for the Social Sciences; Sage: Thousand Oaks, CA, USA, 2001.

23. Brugha, R.; Varvasovszky, Z. Stakeholder analysis: A review. Health Policy Plan. 2000, 15, 239-246. [CrossRef]

24. Calderón García, H.; Cervera Taulet, A.; Tubillejas Andrés, B.; Fayos Gardó, T. Selección del modo de entrada en un mercado internacional: Valoración de las capacidades empresariales, la estrategia empresarial y las percepciones de los problemas de la internacionalización. Inf. Comer. Esp. Rev. Econ. 2007, 839, $143-162$.

25. Fayos, T.; Calderón, H.; Mir, J. El éxito en la internacionalización de las cooperativas agroalimentarias españolas. Propuesta de un modelo de estudio desde la perspectiva del marketing internacional. Ciriec Esp. Rev. Econ. Publica Soc. Coop. 2011, 72, 42-72.

26. Hahn, T.; Pinkse, J.; Preuss, L.; Figge, F. Tensions in corporate sustainability: Towards an integrative framework. J. Bus. Ethics 2015, 127, 297-316. [CrossRef]

27. Arino, A.; la Torre, J.; Doz, Y.; Ring, P.S.; Lorenzoni, G. Process issues in international alliance management: A debate on the evolution of collaboration. In Advances in Comparative International Management; Elsevier: Amsterdam, The Netherlands, 2002; Volume 14, pp. 173-219.

28. Contractor, F.J.; Lorange, P. The Growth of alliances in the knowledge-based economy. Int. Bus. Rev. 2002, 11, 485-502. [CrossRef]

29. Johanson, J.; Wiedersheim-Paul, F. The internationalization of the firm: Four Swedish cases. J. Manag. Stud. 1975, 12, 305-322. [CrossRef]

30. Núñez, A.M. La joint venture contractual en el ámbito internacional. Rev. Electron. Estud. Int. 2014, $27,3-62$.

31. Pauleau, C. Incidencia del Derecho en la Creación y Funcionamiento de las Joint Ventures. Análisis de la Organización jurídica de las Joint Ventures en la Unión Europea, Con Especial Referencia a España. Ph.D. Thesis, Universitat Pompeu Fabra, Barcelona, Spain, 2003. 
32. Elkington, J. Towards the sustainable corporation: Win-win-win business strategies for sustainable development. Calif. Manag. Rev. 1994, 36, 90-100. [CrossRef]

33. WCED, S.W.S. World commission on environment and development. Our Common Future 1987, 17, 1-91.

34. Holden, E.; Linnerud, K.; Banister, D. Sustainable development: Our common future revisited. Glob. Environ. Chang. 2014, 26, 130-139. [CrossRef]

35. Nations, U. The Sustainable Development Goals Report; United Nations: New York, NY, USA, 2016.

36. Briner, R.B.; Denyer, D. Systematic review and evidence synthesis as a practice and scholarship tool. Handb. Evid. Based Manag. Co. Classr. Res. 2012, 112-129. [CrossRef]

37. Moral-Muñoz, J.A.; Herrera-Viedma, E.; Santisteban-Espejo, A.; Cobo, M.J. Software tools for conducting bibliometric analysis in science: An up-to-date review. Prof. Inf. 2020. [CrossRef]

38. Aria, M.; Cuccurullo, C. bibliometrix: An R-tool for comprehensive science mapping analysis. J. Inf. 2017, 11, 959-975. [CrossRef]

39. R Core Team. R: A Language and Environment for Statistical Computing; R Foundation for Statistical Computing: Vienna, Austria, 2019.

40. Chertow, M. “Uncovering” industrial symbiosis. J. Ind. Ecol. 2007, 11, 11-30. [CrossRef]

41. Matta, J.; Alavalapati, J. Perceptions of collective action and its success in community based natural resource management: An empirical analysis. For. Policy Econ. 2006, 9, 274-284. [CrossRef]

42. Duff, G.; Garnett, D.; Jacklyn, P.; Landsberg, J.; Ludwig, J.; Morrison, J.; Novelly, P.; Walker, D.; Whitehead, P. A collaborative design to adaptively manage for landscape sustainability in north Australia: Lessons from a decade of cooperative research. Landsc. Ecol. 2009, 24, 1135-1143. [CrossRef]

43. Kumaraswamy, M.M.; Shrestha, G. Targeting'technology exchange'for faster organizational and industry development. Build. Res. Inf. 2002, 30, 183-195. [CrossRef]

44. Chen, J.Y.; Dimitrov, S.; Pun, H. The impact of government subsidy on supply Chains' sustainability innovation. Omega 2019, 86, 42-58. [CrossRef]

45. Devapriya, K.; Ganesan, S. Technology transfer through subcontracting in developing countries. Build. Res. Inf. 2002, 30, 171-182. [CrossRef]

46. Kepa Brian Morgan, T.; Sardelic, D.; Waretini, A. The Three Gorges Project: How sustainable? J. Hydrol. 2012, 460, 1-12. [CrossRef]

47. Sagers, M. The regional dimension of Russian oil production: Is a sustained recovery in prospect? Eurasian Geogr. Econ. 2006, 47, 505-545. [CrossRef]

48. Hosseininia, G.; Ramezani, A. Factors influencing sustainable entrepreneurship in small and medium-sized enterprises in Iran: A case study of food industry. Sustainability 2016, 8, 1010. [CrossRef]

49. Ichijo, K.; Kohlbacher, F. The Toyota way of global knowledge creation the 'learn local, act global' strategy. Int. J. Autom. Technol. Manag. 2007, 7, 116-134. [CrossRef]

50. Shah, K. Choice and control of international joint venture partners to improve corporate environmental performance. J. Clean. Prod. 2015, 89, 32-40. [CrossRef]

51. Maqsoom, A.; Charoenngam, C.; Awais, M. Internationalization process of Pakistani contractors: An exploratory study. In Proceedings of the ICCREM 2013: Construction and Operation in the Context of Sustainability, Karlsruhe, Germany, 10-11 October 2013; pp. 59-72. ISBN 9780784413135.

52. Yun, J.; Lee, M.; Park, K.; Zhao, X. Open innovation and serial entrepreneurs. Sustainability 2019, 11, 5055. [CrossRef]

53. Toppinen, A.; Lähtinen, K.; Leskinen, L.; Österman, N. Network co-operation as a source of competitiveness in medium-sized Finnish sawmills. Silva Fenn. 2011, 45, 743-759. [CrossRef]

54. Rosner, B.; Edwards, C. The Transport System for High Grade McArthur River Uranium Ore; World Nuclear Association: London, UK, 1997; pp. 341-350.

55. Medina de Lemus, M. Contratos de Comercio Exterior; Dykinson: Madrid, Spain, 1998.

56. Ohmae, K. El próximo Escenario Global: Desafíos y Oportunidades en un Mundo Sin Fronteras; Grupo Editorial Norma: Bogotá, Colombia, 2015. 
57. Huang, Y. One country, two systems: Foreign-invested enterprises and domestic firms in China. China Econ. Rev. 2003, 14, 404-416. [CrossRef]

58. Puyo Arluciaga, A.M. Reflexiones en torno a las formas de implantación de empresas extrenjeras en Cuba. Rev. Dir. Adm. Empres. 2012, 19, 29-62.

59. Okafor, C. Joint development: An alternative legal approach to oil and gas exploitation in the Nigeria-Cameroon maritime boundary dispute? Int. J. Mar. Coast. Law 2006, 21, 489-522. [CrossRef]

60. Klein, A.; Chapekar, M. Innovate America: The technology innovation program at NIST. J. Commer. Biotechnol. 2009, 15, 293-300. [CrossRef]

61. Mahmod, A.A.W.; Mohd, S.; Masirin, M.I.M.; Tajudin, S.A.A.; Bakar, I.; Zainorabidin, A.; Kifli, A.Z.; Hua, L.J. Construction of buildings on peat: Case Studies and Lessons Learned. In Proceedings of the MATEC Web of Conferences, Melaka, Malaysia, 1-2 December 2015; EDP Sciences: Les Ulis, France, 2016; Volume 47, p. 03013.

62. Baardsen, E. ADB's new approaches to project financing. Int. J. Hydropower Dams 2003, 10, 67-73.

63. Roux, D.; Seelos, K. Building on partnerships with aboriginal communities. Int. J. Hydropower Dams 2004, 11, 47-60.

64. Wiblin, S. Integrating travel behaviour change for workers, shoppers and residents at an outer suburban centre. In Proceedings of the 33rd Australasian Transport Research Forum, Canberra, Australia, 29 September-1 October 2010; Volume 33.

65. Harris, S. Power house. Engineer 2011, 296, 26-27.

66. Tetteh, M.; Chan, A.; Nani, G. Combining process analysis method and four-pronged approach to integrate corporate sustainability metrics for assessing international construction joint ventures performance. J. Clean. Prod. 2019, 237, 117781. [CrossRef]

67. Li, C.F.; Cao, Y.Y.; Yang, J.C.; Yang, Q.Q. Scenario analysis on sustainable development of Sino-Singapore Tianjin Eco-city based on emergy and system dynamics. Chin. J. Appl. Ecol. 2015, 26, 2455-2465.

68. Ludiman, A.; Sorrell, S.; Hothi, K.; Aujla, S. A new model to deliver housing: Land at Barton, Oxford. J. Urban Regen. Renew. 2012, 5, 203-211.

69. Fog, C.L. The acoustical design of Muscat and Salalah international airports, Oman. In Proceedings of the INTER-NOISE and NOISE-CON Congress and Conference Proceedings. Institute of Noise Control Engineering, Lisbon, Portugal, 13-16 June 2010; pp. 3151-3159.

70. Feng, Y.; Fujiwara, T. A study on foreign investment and development of water business in China: Based on agency approach. In Proceedings of the International Technology Management Conference, Dallas, TX, USA, 25-27 June 2012; pp. 393-397. [CrossRef]

71. Yamazaki, H. Introduction of advanced Metso Paper Technology into China. Kami Gikyoshi/Jpn. Tappi J. 2004, 58, 1-8.

72. Redfern, L. High Performance Computing (HPC) Wales and the next generation workforce: Strategies to ensure propagation. MRS Online Proc. Libr. Arch. 2013, 1583, 38-46. [CrossRef]

73. Hebblewhite, B. International education of mining engineers - An update on the australian experience and international opportunities for collaboration. Min. Eng. 2010, 62, 37-43.

74. Shiraishi, N.; Iijima, J. Business process-based view of inter-firm relationships. In Proceedings of the PACIS 2008 - 12th Pacific Asia Conference on Information Systems: Leveraging ICT for Resilient Organizations and Sustainable Growth in the Asia Pacific Region, Suzhou, China, 4-7 July 2008.

75. Swierczek, F.; Dhakal, G. Learning and its impact on the performance of manufacturing joint ventures in developing countries. Technovation 2004, 24, 53-62. [CrossRef]

76. Bandyopadhyay, S.; Dutta, M. Opportunities and Challenges in Development: Essays for Sarmila Banerjee; Springer: Singapore, 2019; pp. 1-564.

77. Ge, Y.; Chen, Y. Foreign ownership and productivity of joint ventures. Econ. Dev. Cult. Chang. 2008, 56, 895-920. [CrossRef]

78. Jeong, J.; Kim, J.; Son, H.; Nam, D.I. The role of venture capital investment in startups' sustainable growth and performance: Focusing on absorptive capacity and venture capitalists' reputation. Sustainability 2020, $12,3447$. [CrossRef] 
79. Joshi, K.; Chandrashekar, D.; Brem, A.; Momaya, K. Foreign venture capital firms in a cross-border context: Empirical insights from India. Sustainability 2019, 11, 6265. [CrossRef]

80. Kimseng, T.; Javed, A.; Jeenanunta, C.; Kohda, Y. Sustaining innovation through joining global supply chain networks: The case of manufacturing firms in Thailand. Sustainability 2020, 12, 5259. [CrossRef]

81. Lim, C.; Chong, Y.; Sutjipto, M. Creating value through sustainable business practices. Eur. J. Tour. Res. 2012, 5, 118-128.

82. Ma, X.; Tang, Z.; Wang, D.; Gao, H. The influence of risk culture on the performance of international joint-venture securities. Sustainability 2020, 12, 2603. [CrossRef]

83. Maxwell, S. Factors for success in new technology development. J. Am. Water Work. Assoc. 2004, 96, 38-40. [CrossRef]

84. Rudie, R. Corgill Dow sows seeds of future fibers; will build $\$ 300$ million PLA polymer plant. Int. Fiber J. 2000, 15, 8-12.

85. Wu, B.; Wang, Y.; Qin, W. On the investment modes of RJVs to solve SMEs' dilemma in independent innovation. In Proceedings of the 2010 International Conference on Management and Service Science, IEEE, Wuhan, China, 24-26 August 2010; pp. 1-7.

86. Khan, F. Development of Environmental Operational Controls for Risk Minimization and Environmental Clearance for Onshore Drilling Operations. In Proceedings of the SPE International Conference on Health, Safety and Environment in Oil and Gas Exploration and Production. Society of Petroleum Engineers, Kuala Lumpur, Malaysia, 20-22 March 2002.

87. Kurian, J. High performance polymers made with renewable resources. In Proceedings of the 2007 Annual Meeting, Chicago IL, USA, 5-7 January 2007; Volume 1, p. 388.

88. Weber, N. City rejects recycled newsprint mill. Recycl. Pap. News 2004, 14, 11-12.

89. Matchaya, G.; Nhamo, L.; Nhlengethwa, S.; Nhemachena, C. An overview of water markets in Southern Africa: An option forwater management in times of scarcity. Water 2019, 11, 1006. [CrossRef]

90. Dolle, G. New opportunities offered by sustainable development. Rev. Metall. 2005, 11, 16-18.

91. Bridger, G.; Hao, L.T.; Nhan, N.T. Building sustainability through water company and community linkages. In Proceedings of the 30th WEDC International Conference, Vientiane, Laos, 25-29 October 2004.

92. Grainger, S.; Sherry, E.; Fondahl, G. The John Prince Research Forest: Evolution of a co-management partnership in northern British Columbia. For. Chron. 2006, 82, 484-495. [CrossRef]

93. Hiraoka, L. Foreign development of China's motor vehicle industry. Int. J. Technol. Manag. 2001, 21, 496-512. [CrossRef]

94. Financial fillip for hydro in the developing world. Int. J. Hydropower Dams 2003, 10, $64-66$.

95. Race, D.; Desmond, H. Forestry out-grower schemes: A Review from Selected Countries. J. Sustain. For. 2002, 15, 79-98. [CrossRef]

96. Reed, D. Not just cheap labour, there are growing opportunities in East Europe. Urethanes Technol. 2003, $20,28$.

97. Boschee, P. E \&P experience and innovation distinguish OTC 06. Offshore 2006, 66, 30.

98. Boschee, P. Asia-Pacific EI\&P activity maintains fast growth. Offshore 2006, 66, 50.

99. Adams, J.; Wübbels, T.; Ester, H.; Schmale, K.; Meyn, M. New technologies for BOF primary gas cleaning: 2nd generation of drytype ESP and Hydro Hybrid Filter technology. Iron Steel Rev. 2011, 2, 201-215.

100. Aggarwal, V.; Kapoor, M. Multigroup analysis of higher-order model of knowledge variables in the context of global ventures through PLS-SEM. South Asian J. Bus. Stud. 2020. [CrossRef]

101. Asgary, N.; Thamhain, H. Effective leadership for culturally diverse technology projects. In Proceedings of the PICMET'08-2008 Portland International Conference on Management of Engineering \& Technology, Cape Town, South Africa, 27-31 July 2008; pp. 1345-1350.

102. Cocks, R.; Ho, G.; Anda, M.; Dallas, S. An assessment of Kalgoorlie consolidated gold mines and boddington gold mine water sources and proposed water auditing framework underpinning improved water allocation compliance and reporting. Trans. Inst. Min. Metall. Sect. Min. Technol. 2009, 118, 225-231. [CrossRef]

103. Corner, S. Home and away. Total. Telecom 2004, 1, 16-18

104. Gagro, D. Europe remains a strong market. Eur. Coatings J. 2012, 1, 14-16. 
105. Glasgow, B. Chemical Credit Outlook for 2004 Shows Signs of Solid Improvement. Chem. Mark. Report. 2004, $265,1-16$.

106. Hikosaka, T. Introduction of Environmentally Conscious Transformer Products. In Proceedings of the 2011 International Conference on Electrical Insulating Materials, Tokyo, Japan, 6-10 September 2011.

107. Kim, I. The Promising World of Bio-oxidation. Chem. Eng. Prog. 2004, 100, 8-11.

108. Lindstrand, N. The biorefinery-A new forest industry is emerging Joint ventures make way for new products. Appita J. 2008, 61, 263.

109. Lu, C. Flying with the dragon. ABB Rev. 2008, 1, 5-8.

110. Elamroni, A.; Xuan, M.; Druic, E. Negative Factors Affecting Decisions Making in Integrated Construction Joint Ventures of China's Contractors in Malaysia. In Proceedings of the 18th International Business Information Management Association, Istanbul, Turkey, 9-10 May 2012; Volume 4.

111. Pan, Q.; Zhang, J. Innovations drive enterprises to sustainable development: An empirical research on Delixi-electric Co.Ltd in WenZhou. In Proceedings of the 2010 International Conference on Management and Service Science, Wenzhou, China, 24-26 August 2010; pp. 1-6.

112. Pilling, M. The quiet professional. Airl. Bus. 2005, 21, 36-40. 
113. Rai, A.; Howell, R.; Weatherwax, T.; Sandbak, L.; Kallu, R. A case study for Northern Nevada single excavation! Shaft- Technical Limit: Width and depth? In Proceedings of the 49th US Rock Mechanics/Geomechanics Symposium. American Rock Mechanics Association (ARMA), San Francisco, CA, USA, 28 June-1 July 2015; Voume 4, pp. 2440-2448.

114. Ryu, M.; Park, J.; Kwak, K. Joint ventures between online portals and news publishers: Will they be an alternative to symbiosis? Sustainability 2020, 12, 3296. [CrossRef]

115. Schuster, L.; Hunter, M. Human Resources Strategy and Change: Essentials of Mergers, Acquisitions, and Joint Ventures; Springer: Berlin/Heidelberg, Germany, 2016; pp. 1375-1394.

116. Sherman, L. Performance, processability, and sustainability. Plast. Technol. 2012, 58, 38-45.

117. Stauffer, D. Sustainability of U.S. pine chemicals threatened. For. Chem. Rev. 2010, 120, 12-13.

118. Taubert, M. New generation of mobile rail millers making its way [Neue Generation Mobile Schienenfräsen im Werden]. ZEVrail 2012, 136, 427-429.

119. Tullo, A. World chemical outlook: Canada. Chem. Eng. News 2004, 82, 21-22. [CrossRef]

120. Volkmann, E. Eco beauty. Wool Rec. 2008, 167, 30-32.

121. Woolnough, P. Redeveloping an icon. Civ. Eng. Aust. 2004, 76, $26-31$.

122. Young, I. Riding Asia's industry upcycle. Chem. Week 2005, 167, 28.

123. Global Apparel Business Update. 2012. Available online: https://www.textilesintelligence.com/tistoi/index. $\mathrm{cfm}$ ? pageid=3\&repid=TISTOI\&issueid=157\&artid=1807 (accessed on 29 October 2020).

124. Ge, H.; Chen, S.; Chen, Y. International alliance of green hotels to reach sustainable competitive advantages. Sustainability 2018, 10, 573. [CrossRef]

125. O'neill, J. Building Better Global Economic BRICs; Goldman Sachs Global Economics Paper No. 66; Goldman, Sachs \& Co.: London, UK, 2001.

126. Lu, Y. Joint Venture success in China: How should we select a good partner? J. World Bus. 1998, 33, 145-166. [CrossRef]

Publisher's Note: MDPI stays neutral with regard to jurisdictional claims in published maps and institutional affiliations.

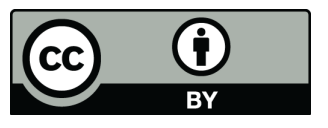

(C) 2020 by the authors. Licensee MDPI, Basel, Switzerland. This article is an open access article distributed under the terms and conditions of the Creative Commons Attribution (CC BY) license (http:/ / creativecommons.org/licenses/by/4.0/). 